\title{
SENHOR B
}

Leonardo Wittmann é doutorando em Escrita Criativa pela Pontifícia Universidade Católica do Rio Grande do Sul. E-mail:

leowittmann@gmail.com

$*$

Meu pai se considerava um dos grandes escritores da época, embora nunca tivesse publicado um conto sequer. Seus trabalhos consistiam, basicamente, de pequenas anotações (ou fragmentos, como gostava de chamá-los); pensamentos soltos para um texto ainda invisível. Um texto que, um dia, e de acordo com ele, o propulsionaria ao sucesso inevitável. Morava num pequeno apartamento, que também utilizava como gabinete para escrever, em Montmartre. Eu o visitava três vezes por semana. Meu pai sentia que o momento de iniciar seu livro era agora. Necessitava de paz e disciplina. Eu precisava, igualmente, de certa rotina de trabalho: depois de quase um ano, consegui me estabelecer como consultor de roteiros cinematográficos (filmes de baixo padrão, em sua maioria). Se, por um lado, meu pai batalhava para se tornar um escritor conhecido, a minha escolha parecia me levar a um anonimato eterno.

Tudo se desenvolvera desta forma nos últimos meses, até que, dois dias antes, não o encontrei em seu apartamento abarrotado de livros. Suas anotações também haviam sumido. A governanta do prédio me informou que ele saíra na quarta pela manhã e não voltara. O mais lógico era isto: ele se mudara, se isolara em um novo local a fim de terminar seu livro. Pensei na única pessoa a quem meu pai confiaria os detalhes de seu paradeiro, mesmo esta sendo quase uma desconhecida para ele: o senhor B.

Com isto em mente, e com o discurso já preparado, me aproximei da mesa do senhor B no Café de Flore (comia salsichas de Frankfurt e tinha uma caderneta à mesa). Perguntei se podia me sentar. Ele assentiu com um sorriso. Apresentei-me. Àquela época, ele ministrava um curso sobre a preparação do romance (aos sábados pela manhã), que meu pai frequentava. Este era um dos únicos motivos que o faziam sair de casa (quando nos encontrávamos, raramente jantávamos fora), excitado por ser integrante de um universo, de um mundo, onde poderia realizar seu sonho de longa data. Meu pai havia descrito algumas aulas do senhor B, e devo dizer que nunca vi nele tamanha alegria ao se referir a outra pessoa.

O senhor B vestia um blusão azul de lã fina e uma camisa branca por baixo, da qual se via apenas parte da gola, além de um blazer bege, que repousava no encosto da cadeira. Ouviu-me atentamente. Sim, se lembrava de meu pai. Eu esperava uma resposta concreta, mas ouvi apenas uma negativa quanto ao conhecimento de seu paradeiro. É claro. Por que 
este conceituado professor do Collège haveria de saber o destino de um possível escritor de mais de cinquenta anos? Levantei-me e agradeci pela ajuda prestada. Ele lamentou não poder ser mais útil. Pediu que anotasse meu nome e telefone num papel, em caso de lembrar-se de algo. Acho que o fez não por educação, mas por curiosidade. Entreguei meus dados, agradeci mais uma vez e olhei em volta (um casal no balcão e um senhor solitário de gorro de lã numa mesa ao fundo, isolado e quase imperceptível - imaginei se, futuramente, aquele seria o meu pai). Saí pela agradável brisa parisiense.

$\mathrm{S}$ chegou ao meu apartamento uma hora antes do combinado. Ainda me recuperava da falta de respostas da noite anterior, o que dificultou nossa conversa sobre um roteiro que precisava entregar dali a três dias. Ela usava belos óculos cor de marfim, o cabelo crespo solto, sua pasta branca a tiracolo lhe conferindo um ar de seriedade informal, prestes a ruir com a mais rasa piada. Ao contrário de mim, $\mathrm{S}$ havia se destacado logo após a faculdade, trabalhando como tradutora de textos na Gallimard e, mais tarde, como roteirista de séries de TV - uma de real qualidade sobre a juventude de Racine - e longasmetragens (bons, em sua maioria). Alcancei a função de consultor com alguma ajuda sua. $\mathrm{S}$ havia lido o tal roteiro e, embora o considerasse com poucas virtudes (personagens simplórios), também reconhecia alguns méritos (um homem que carrega um sofá pelo Alasca). O telefone tocou. Atendi.

Mais uma vez no Flore. Desculpei-me pelo incômodo, mesmo tendo sido o Senhor B a entrar em contato. Respondeu que sempre tivera dificuldade em trabalhar à tarde e que por isso não me preocupasse. Reparei num calhamaço de folhas postado na beirada da mesa. Ele pediu que o examinasse. Eram quase trinta páginas datilografadas. Recebera-o por correio, na noite anterior. No momento em que eu o abordara, menos de dezoito horas antes, a parte inicial do manuscrito saíra do completo anonimato e do plano das ideias para a porta do senhor B. É estupendo, me disse, depois de acender um cigarro e deixar a fumaça preencher parte do ambiente.

Durante a conversa, o senhor B olhava em volta à procura de alguém que, me parecia, nunca iria chegar. Observou ainda alguns jovens que iam e vinham no café, mas nenhum de maneira mais demorada. Imaginei sua rotina no Flore, lendo o Le Monde, levantando a cabeça várias vezes (sem se distrair da leitura) para capturar o local fixamente, e depois flanando pelas ruas ou escrevendo em seu apartamento. Um homem um pouco à parte, talvez em busca de um abrigo verdadeiro.

Fomos ao apartamento de meu pai. Debaixo da mesa do escritório, encontrei algumas folhas rasuradas. Nada, pareceu-me, relacionado com o seu destino. Enquanto me detinha neste trabalho mais íntimo, o senhor B examinava a estante de livros. Por vezes, sacou sua caderneta e tomou notas. Tive a impressão de que a sala, e o apartamento inteiro, 
formava a cena de um crime impronunciável, e que o senhor B era um detetive - um detetive literário - atrás de qualquer indício, de qualquer pista, por menor que fosse. Perguntei-me, também, se, caso achássemos meu pai, o senhor B escreveria algo sobre ele e seus inúmeros textos inacabados.

$\mathrm{Li}$ as quatro páginas iniciais do calhamaço. Um homem franzino, com roupas esfarrapadas, caminha por um vasto campo isolado; o tal personagem (meu pai?) carrega uma maleta a tiracolo, com meia dúzia de páginas escritas. De dez em dez quilômetros, joga uma página ao vento. O senhor B informou que tinha outro compromisso (janta com amigos no Palette), mas que entraria em contato mais uma vez. Pediu que eu ficasse com o livro por enquanto. Concordei.

$\mathrm{Na}$ manhã seguinte, carregando o manuscrito debaixo do braço, andei pelas ruas de Montmartre com uma improvável esperança de encontrar meu pai. Talvez acreditando que esse simples ato, por menos lógico ou são que fosse, traria algo de concreto para mudar a situação. Sentei-me num banco e folheei as páginas. Li e reli atentamente. Era possível rastreá-lo por meio delas? Se ele fosse, de fato, aquele escritor ermitão da narrativa, qual o lugar ideal em que se refugiaria? Com isso em mente, decidi ir até a Gare de Lyon para estudar os itinerários dos diversos trens que partiam diariamente.

Já na estação, observei os transeuntes, pessoas em constante deriva e misturadas numa rede gigante e confusa. Imaginei se meu pai teria passado por alguma delas. Observei os bancos, as bilheterias e as entradas (era um esforço inútil, mas necessário). Depois de uma hora à procura de informações, descobri que um dos trens matinais passava pelo vilarejo de $\mathrm{M}$, um lugar de poucos habitantes, casas antigas e um vasto campo. Comprei uma passagem para o dia seguinte.

O telefone tocou enquanto $\mathrm{S}$ e eu realizávamos os últimos ajustes no roteiro. Era o senhor B, perguntando por novidades sobre o caso (a palavra "caso" me fez idealizálo, mais uma vez, como um detetive atento e dedicado). Relatei a minha ida à Gare de Lyon e a viagem da próxima manhã. Perguntou se seria inconveniente acompanhar-me na viagem. Fiquei calado, surpreso por esse pedido tão curioso. É claro que não, lhe respondi. Ele agradeceu e disse até amanhã, mon cher.

Descemos na estação de M. O local apresentava bancos de madeira podres, janelas laterais empoeiradas e, das cinco bilheterias, apenas duas funcionavam. Passamos por ruas estreitas, íngremes e silenciosas, percorridas vez ou outra por uma ciclista ou por crianças com uma bola de futebol debaixo do braço. O senhor B levava as mãos nos bolsos e seu olhar era investigativo antes de contemplativo. Interrompemos a caminhada 
inúmeras vezes à procura de informações, mas ninguém avistara um andarilho ou morador recém-chegado. Decidimos ir até o vasto campo em torno da cidade.

Depois de uma longa caminhada, o senhor B chamou minha atenção para um casebre de madeira ao longe, isolado numa colina. Ao nos aproximarmos do local, imaginei meu pai trabalhando de maneira árdua em seu manuscrito, compenetrado como um monge em terminar sua desejada obra. Um monge solitário que enfrenta seus demônios e, ao mesmo tempo, usufrui da tranquilidade de um espaço mínimo. Espiei pelo vão da porta. Pensei no material que poderia estar ali: algumas anotações feitas à mão, desconexas, além de páginas datilografadas. Estas tratariam do mesmo andarilho que, após escrever seu livro, o espalha pelo vento, deixando-o fragmentado? Ao mesmo tempo, se meu pai criara um personagem de si mesmo, não estaria ele a milhas de distância, andando de pés descalços e se desfazendo de sua obra? Empurrei a porta e ela rangeu de maneira discreta. $\mathrm{O}$ espaço revelado não continha nada, exceto mofo nas paredes descascadas. O senhor B tirou seu blazer e carregou-o no ombro enquanto examinava o casebre. Caminhei para longe.

Já em Paris, agradeci ao senhor B pela ajuda. Convidou-me para um último café no Flore, na tarde seguinte. Aceitei. Ele se distanciou no horizonte fervilhante da Paris noturna.

Entreguei as páginas para o senhor B e lhe disse que podia fazer com elas o que bem entendesse. Perguntou-me se algum dia encontraríamos o livro pronto debaixo de nossas portas. Não soube o que responder, então apenas sorri. Observei sua caderneta na mesa. O senhor B, antecipando a minha fala, disse que anotara uma série de ideias nos últimos dias, principalmente depois que eu o abordara, algumas noites atrás. Um momento de silêncio tomou conta de nós. Encarei-o nos olhos, buscando por algo que ele parecia resolvido a não expor. Fez um comentário breve sobre sua mãe, falecida dois anos antes. Percebi que naquelas palavras talvez residisse o motivo de sua ajuda. E talvez o motivo da sua discreta melancolia. Os dois ali, à procura de algo inalcançável ou que nos fora tirado há muito tempo: um ponto de referência. O senhor B quis pagar o café, mas disselhe que não era necessário. Colocou as páginas em sua maleta e me dirigiu um sorriso desconsolado. Levantou-se. Cuide-se, meu amigo, ele disse, e se foi. 